\title{
"Economia Civil" e "Polícia" no ensino do "Direito Pátrio" em Coimbra: Notas sobre as "Prelecções" de Ricardo Raymundo Nogueira ${ }^{1}$
}

\author{
Airton Cerqueira-Leite Seelaender ${ }^{2}$
}

Indicando as opções políticas disponíveis para a elite dos letrados portugueses no final do século XVIII, bem como o que podia ser dito e convinha ser dito no ensino coimbrão do "Direito Pátrio", a linguagem e os posicionamentos das "Prelecções" de Nogueira legitimavam a expansão da atividade legislativa real e a submissão do meio jurídico às leis do absolutismo reformador. Os conceitos de "polícia" e "economia" tendiam a marcar esferas em que o monarca, implicitamente equiparado ao pai de família na gestão da "grande casa" do reino, podia regular, ordenar e impor condutas, sem os bloqueios que a tradição jurídica havia, desde a Idade Média, imposto na prática aos reis.

Palavras-chave: Polícia - Direito Pátrio - Ricardo R. Nogueira

"Civil Economy" and "Police" in the Teaching of "the Law of the Fatherland" in Coimbra: Notes on the Preleç̧ões of Ricardo Raymundo Nogueira

As a demonstration of the political choices available to the educated Portuguese elite at the end of the 18th century, as well as of what could be said and what was permissible to be said in the teaching of "the Law of the Fatherland" at the University of Coimbra, the language and arguments of the "Prelecções" of Nogueira legitimated the growth of royal law-making and the submission of the courts to the decisions of a Reformist Abso-

\footnotetext{
${ }^{1}$ Artigo recebido e aprovado para publicação em fevereiro de 2011.

${ }^{2}$ Doutor em Direito pela J. W. Goethe-Universität (Frankfurt), professor de História do Direito e de Direito Constitucional da Universidade Federal de Santa Catarina, pesquisador do CNPq.
} 
lutism. The concepts of "police" and "economy" were used to denote spheres in which the monarch, equated by implication with the father of a family in the governance of the "great house" which was the kingdom, might make ordinances, precepts and rules of conduct, without the restrictions which judicial tradition had imposed on royal practices since the Middle Ages.

Keywords: Police -The Law of the Fatherland - Ricardo R. Nogueira

\section{«Économie civile» et «police» dans l'enseignement du droit portugais (Direito Pátrio) à Coimbra : notes sur les Prelecções de Ricardo R. Nogueira}

En accord avec les options politiques disponibles aux lettrés portugais de la fin du XVIII siècle ainsi qu'avec ce qui pouvait et convenait d'être dit dans l'enseignement du droit portugais (Direito Pátrio) à Coimbra, le langage et les propositions des Leçons de Nogueira prêtaient une légitimité à l'expansion de l'activité législative royale, et assuraient la soumission des juges et des avocats aux lois de l'absolutisme réformateur. Les concepts de «police» et «économie» tendent à marquer des sphères dans lesquelles le souverain, implicitement comparé au père de famille dans la gestion de la "grande maison» du royaume, pouvait réguler, ordonner et imposer des procédés sans les barrières que la tradition juridique interposait à l'action des rois depuis le Moyen Âge.

Mots-clés: Police - Droit portugais - Ricardo R. Nogueira

1

Corruptela do termo erudito "política", o termo "polícia" vinculava-se em várias línguas, no início da Idade Moderna, às ideias de "governo" e "bom governo" dentro de um reino ou cidade - e daí às de "boa ordem", "ordem" e mesmo "civilidade". ${ }^{3}$ No meio urbano, a palavra "polícia" era então frequentemente relacionada à gestão interna da cidade nos aspectos que mais afetavam seu

\footnotetext{
${ }^{3}$ Sobre a evolução do conceito de "polícia" no Antigo Regime, cf. o quadro geral descrito em A. C. L. Seelaender, "A 'polícia' e as funções do Estado", Revista da Faculdade de Direito UFPR, n. 49, 2009, p. 73-87; bem como a recente síntese de Thomas Simon, Gute Policey: Ordnungsleitbilder und Zielvorstellungen politischen Handelns in der Frühen Neuzeit, Frankfurt am Main/M. V. Klostermann, 2004. Cf., também, a bibliografia ali citada, que inclui os dados e as reflexões de Michael Stolleis, Geschichte des öffentlichen Rechts in Deutschland, München, C. H. Beck, 1988, v. 1; Michael Stolleis (org.), Policey in Europa der frühen Neuzeit, Frankfurt/M. V. Klostermann, 1996; F. L. Knemeyer, "Polizei". In: O. Brunner, W. Conze, R. Koselleck, (org.), Geschichtliche Grundbegriffe, Stuttgart, Klett-Cota, 1978, v. 4, p. 875-897; e Hans Maier, Die ältere deutsche Staats- und Verwaltungslehre, 2. ed., München, C. H. Beck, 1980. Para a evolução do conceito em Portugal, cf. A. C. L. Seelaender, Polizei, Ökonomie und Gesetzgebungslehre, Frankfurt/M. V. Klostermann, 2003, e A. C. L. Seelaender, "A polícia e o rei-legislador". In: E. Bittar, História do direito brasileiro, São Paulo, Atlas, 2003, p. 91-108.
} 
dia a dia (conservação de ruas, abastecimento de água, limpeza urbana, prevenção de incêndios, controle de pesos e medidas no comércio etc.).

Fazia-se comumente uma equiparação entre governo do reino ("polícia") e governo da casa ("economia"). Isso permitia estender ao primeiro o que se via como atributo do segundo: um amplíssimo direito de regular a convivência e de reprimir maus comportamentos, para que se preservassem a paz doméstica e a "boa ordem". Dentro desse quadro, também podiam surgir "ordenações de polícia” (Policeyordnungen) para combater o jogo, a sedução de freiras, o consumo excessivo de álcool, a prostituição, a vadiagem, o luxo corruptor de almas e ocultador das diferenças estamentais, o bandoleirismo e outras práticas vistas como incompatíveis com essa mesma "boa ordem".

Com o tempo, à medida que se multiplicavam as guerras na Europa, vários governos passaram não só a expandir seus exércitos e armadas, mas também a dar maior atenção às bases econômicas e populacionais do poderio militar. Visando ao crescimento populacional e ao aumento da arrecadação, esforçaram-se então para desestimular o celibato, promover a imigração, impor padrões de higiene, estimular as manufaturas, instituir companhias coloniais, combater o ócio, dar maior segurança aos comerciantes, facilitar a circulação de bens etc. $\mathrm{O}$ termo "polícia" também foi, então, adotado para designar o imenso leque de atividades e opções políticas assumidas pela Coroa, na tentativa desta de multiplicar e enriquecer seus súditos e, assim, dar ao poderio estatal bases sólidas.

Grosso modo, fenômenos semelhantes se verificaram em Portugal, ainda que com velocidade e intensidade distintas daquelas observáveis na França e nos territórios de língua alemã. Nestes últimos, desde o século XVII os riscos gerados pela crônica instabilidade regional e pelas tentativas das grandes potências de ali aumentar suas áreas de influência empurravam alguns governos para uma escalada armamentista sem precedentes, que demandava, para ser sustentável, a contínua expansão e o aperfeiçoamento das estruturas estatais relacionadas ao alistamento militar, à arrecadação tributária e ao fomento econômico. O interesse daí gerado favoreceu o desenvolvimento de novas formas de gestão, de novos órgãos estatais e de uma nova ciência - a Policeywissenschaft -, voltada para a reflexão sobre o funcionamento do Estado, seu governo interno e sua atuação

\footnotetext{
${ }^{4}$ Sobre o tema, além das obras supraindicadas e dos estudos de A. M. Hespanha, cf. Daniela Frigo, “Disciplina rei familiariae", Penélope, n. 6, 1991, p. 47-62.
} 
para promover o crescimento populacional e a prosperidade. Dotada de cátedras próprias desde 1727 na Prússia e desde 1752 na Áustria, tal ciência também vicejou por meio de uma literatura específica - nela se destacando autores de língua francesa (Delamare) e sobretudo alemã (Justi, Sonnenfels).

As singularidades do mundo ibérico - e em particular de Portugal - ajudam a explicar, talvez, o relativo atraso com que surgiram, nesse país, os primeiros espaços institucionais para a discussão sobre a "polícia". Teve aqui algum peso, sem dúvida, o intenso e duradouro impacto da Contrarreforma e de seu aparato institucional sobre a cultura lusitana, sobretudo quando dificultou a recepção e a evolução local de uma reflexão mais moderna sobre a política em geral (combatendo mesmo as versões heterodoxas da chamada "política católica") e sobre as funções do Estado. Algum papel há de ter desempenhado nisso, também, a relativa prosperidade do reinado de Dom João V (1706-1750) - mesmo porque, suavizadas as necessidades financeiras do absolutismo, tendia a se arrefecer um pouco o estímulo real ao desenvolvimento e à difusão das técnicas "policiais" de fomento à atividade econômica interna. Seria só no regime pombalino - diante da crise financeira e da instabilidade política, econômica e social da época - que surgiria em Portugal uma Intendência Geral da Polícia (1760). E só no reinado de Dona Maria I, com a criação da Real Academia das Ciências (1779-1780), passaria a existir no país uma instituição permanente destinada a importar, transmitir e produzir técnicas "policiais" para expandir a população e a economia.

Nesse contexto, merece atenção a inserção, no currículo de Coimbra, da disciplina "Direito Pátrio", pela reforma pombalina da universidade (1772). Ainda que as referências à "polícia" tendessem a se resumir, no âmbito dessa nova matéria, a rápidas explanações sobre a legislação nesse campo, o fato é que ali se criava, pela primeira vez no ensino coimbrão, um espaço para transmitir, aos futuros servidores da Coroa, alguma coisa a respeito da "polícia" real e de suas finalidades.

A um leitor apressado, isso até pode parecer insignificante e inócuo, em comparação com a instituição das cátedras centro-europeias. Mas é preciso perceber, no entanto, o desproporcional impacto dessa pequena mudança no quadro específico português, sobretudo considerando a relevância dos jurisconsultos coimbrões na reflexão local sobre o Estado - e, mais ainda, a enorme importância dos juristas egressos de Coimbra dentro do limitado universo de quadros de que dispunha a monarquia portuguesa para compor suas elites dirigentes. 
Registre-se, a par disso, que na recepção, em Portugal, dos tratados setecentistas sobre a "polícia", tiveram destaque docentes coimbrões que transitavam da universidade para as esferas governamentais. Se, nestas, o Traité de la police, de Delamare, não era de todo desconhecido, nos escritos do lente Paschoal de Mello Freire já aparecia mesmo uma reflexão própria sobre os Grundsätze der Policeywissenschaft, de J. H. Justi. ${ }^{5}$ Outro professor - Ribeiro dos Santos, canonista e desafeto de Mello - teve também contato com o pensamento de Sonnenfels, citando-lhe uma "Sciencia do bom governo" que decerto correspondia aos (Grund)sätze der Polizey-, Handlungs- und Finanzwissenschaft. ${ }^{6}$

A importância dessa "recepção elitista", envolvendo homens de Estado e docentes coimbrões, resta ainda mais clara quando a contrastamos com um quadro mais próximo da prática: o da literatura ligada à prática profissional. Obras como o Repertorio das ordenaçoens, de Mendez de Castro, Liber utilissimus, de Cardoso Amaral, Index generalis, de Solano do Vale, e Repertorio das ordenações, e leys, de Jeronymo Pereira, não traziam verbete algum específico sobre a "polícia" ou termos próximos. Em 1743, a Arte de bachareis, de Jeronymo da Cunha, ainda silenciava sobre a teoria da polícia e sobre os tratadistas desse campo, quando expunha os conhecimentos e os livros que um juiz devia ter. ${ }^{7} \mathrm{Na}$ área da "polícia", não surgiu uma literatura local específica nem mesmo acerca das funções dos corregedores, ainda que algumas destas pudessem parecer, ao menos à luz dos modernos tratadistas estrangeiros, tipicamente "policiais" - nessa esfera, a obra de referência seguiu sendo, século XVIII adentro, a velha Politica para corregidores, escrita pelo espanhol Castillo de Bobadilla no fim do século XVI.

Analisar a reflexão sobre a "polícia" em Portugal do Antigo Regime implica, como vemos, estudar também os cursos de Coimbra - e em especial a disciplina "Direito Pátrio" e seus respectivos lentes. Nossa proposta, aqui, consiste em examinar especificamente as preleções de um deles: Ricardo Raymundo Nogueira (1746-1827).

\footnotetext{
${ }^{5}$ Sobre o acesso de Pombal e de Alexandre de Gusmão à obra de Delamare, cf. Seelaender, Polizei..., p. 72 e 121 - onde também se faz uma análise da leitura de Justi por Mello Freire.

${ }^{6}$ Cf. Seelaender, Polizei..., p. 72. Embora o jurista lusitano faça referência a uma edição vienense de 1777, é mais provável que tenha usado uma tradução italiana (Milão, 1784).

${ }^{7}$ Cf. Jeronymo da Cunha, Arte de bacharéis, ou perfeito juiz, Lisboa, J. B. Lerzo, 1743, p. 103-106 e 156 ss.
} 
Refletir sobre a definição de "Leys Politicas" e de "Leys Economicas" era, praticamente, inevitável no ensino de "Direito Pátrio" em Coimbra. Ambos os conceitos constavam do texto da mais importante "lei de interpretação" da era absolutista em Portugal. ${ }^{8}$ Considerando-se, além disso, o crescente interesse da Coroa por matérias então vistas como "policiais" ou "econômicas" e o surgimento de novos órgãos especiais de "polícia" - como a já citada Intendência Geral da Polícia (1760) -, fazia também sentido que os encarregados dessa matéria abordassem, em sua exposição, a "polícia" e suas relações com a atividade legislativa. ${ }^{9}$ Assim sendo, trata-se aqui de examinar como Ricardo Raymundo Nogueira lidava com os conceitos-chave dessa temática - que já tinham, por sinal, uma longa história atrás de si, inclusive na literatura de expressão lusitana. Em que medida se curvava às convenções e significados dominantes no contexto linguístico que o cercava? Como se verificavam, em suas preleções, a recepção e a "releitura" dos termos empregados na literatura estrangeira? Quais usos estratégicos fazia Nogueira, em seus escritos, dos conceitos-chave supramencionados?

É claro que, para uma análise exaustiva dessas questões, forçoso seria tentar reconstruir, na medida do possível, o contexto linguístico das obras de Ricardo Raymundo nos estertores do Antigo Regime. Isso seria aqui impossível - e não só pelas reduzidas dimensões próprias de um artigo. De qualquer modo, tentaremos indicar algumas balizas, abordando rapidamente os escritos de alguns dos outros lentes de "Direito Pátrio". O quadro poderá ser completado pelo leitor verificando nossos estudos anteriores sobre dois juristas que tiveram considerável impacto na matéria: Francisco de Sousa e S. Paio e Mello Freire. ${ }^{10}$

\footnotetext{
${ }^{8}$ Cf. a chamada "Lei da Boa Razão" de 18/8/1769 (sobretudo parágrafo 9), transcrita em José H. Corrêa Telles, “Commentario crítico à Lei da Boa Razão". In: Candido Mendes de Almeida, Auxiliar jurídico [1870], reimpressão, Rio de Janeiro/Lisboa, Gulbenkian, 1985, p. 443-478, p. 454.

${ }^{9}$ Sobre a necessidade de integrar "em um sistema" tanto o direito vindo do passado quanto as numerosas leis novas no âmbito da "indústria, polícia, [...] etc.," cf. as observações do jurista e estadista Tomás Antônio Villanova Portugal em Almeida, Auxiliar..., v. 1, p. XXIX.

${ }^{10}$ Sobre a reflexão desses autores sobre a "polícia" e a "economia", cf. Seelaender, Polizei..., p. 122-175.
} 
Muito embora as obras de Mello Freire e Sousa e S. Paio pareçam ter dedicado mais atenção à "polícia" do que os escritos dos demais lentes, o fato é que estes últimos também contribuíram, no final do século XVIII, para introduzir tal temática no ensino coimbrão do "Direito Pátrio". As Prelecções de direito pátrio de Luiz Joaquim Corrêa da Silva (m. 1797), por exemplo, já tratavam das tarefas "policiais" de determinados servidores da Coroa. ${ }^{11}$ Via a "Justiça" e a "Polícia" como diferentes âmbitos de atuação dos corregedores. Estes deveriam, a seu ver, não apenas cuidar da aplicação da justiça, mas também do "governo, inspecção da policia, e benfeitorias" para "promover a felicidade de todas as terras". ${ }^{12}$

Tendo florescido na era do absolutismo, o gênero "tratado de polícia" apresentava temas-padrão (política comercial, manufaturas, luxo, segurança, educação, proteção dos “bons costumes", crescimento populacional, agricultura, gestão da vida urbana), que nem sempre eram abordados - ou abordados aprofundadamente - a partir da análise do que seria "útil" ou "conveniente" ao Estado, nos escritos relativos ao campo do direito. Seja por isso, seja por não se estruturarem como tratado iluminista, as preleções de Corrêa da Silva não esgotavam tais temas nem os expunham de maneira sistemática.

Como vários de seus contemporâneos, Corrêa da Silva via na existência de uma população numerosa um pressuposto da "felicidade" supracitada. Seus textos revelavam uma grande preocupação com o suposto estagnar do crescimento populacional lusitano desde a Idade Média. ${ }^{13}$ Em contrapartida, o manuscrito

\footnotetext{
${ }^{11}$ Nascido em Minas Gerais, Luiz Joaquim Corrêa da Silva estudou "Leis" a partir de 1769 na Universidade de Coimbra. Doutorou-se em 1778, tornando-se em 1781 professor de Direito Romano e em 1790 lente substituto da matéria "Direito Pátrio". No século XIX, sua contribuição para a primeira edição impressa das Ordenações afonsinas ainda era lembrada. Cf., entre outros, Manuel Paulo Merêa, "Rol dos lentes", Boletim da Faculdade de Direito da Universidade de Coimbra, v. 33, 1957, p. 328; M. P. Merêa, "Notas sobre alguns lentes de Direito Pátrio", Boletim da Faculdade de Direito da Universidade de Coimbra, v. 36, 1960, p. 326; Almeida, Auxiliar..., v. 1, p. XXXIX; Manuel Augusto Rodrigues, Memoria professorum Universitatis Conimbrigensis, Coimbra, Arquivo da Universidade, 1992, v. 2, p. 128; Mário Júlio de Almeida Costa, História do direito português, 2. ed., Coimbra, Almedina, 1995, p. 275.

${ }^{12}$ Ver Luiz Joaquim Correa da Silva, Prelecções de direito pátrio, 1791, 2 v., Biblioteca da Universidade de Coimbra, Manuscrito, v. 2, f. 199-200.

${ }^{13}$ Cf., e.g., Silva, Prelecções..., v. 2, f. 200-203. Estamos aqui diante de um lugar-comum, que pode ter origens locais (Severim de Faria) ou francesas (Montesquieu). Em todo caso, já se comprovou o
} 
coimbrão de suas Prelecções dava bem menos atenção a assuntos relacionados à política comercial e manufatureira. É bem verdade que o autor até expressava opiniões a respeito disso - criticando, por exemplo, em nome dos "progressos do Commercio", a ideia de que o dinheiro, como "sangue da Monarquia", não devia fluir para o exterior. Não obstante, segundo o próprio Corrêa da Silva, não era dentro da matéria "Direito Pátrio" que cabia o aprofundamento de discussões desse jaez. ${ }^{14}$

Os manuscritos de Corrêa da Silva que examinamos referem-se a apenas cinco títulos das "Ordenações filipinas" de 1603. Estes, por sua vez, versavam sobretudo sobre os deveres e competências tradicionais dos juízes e dos advogados. ${ }^{15}$ Não se tratava, pois, de um espaço adequado nem para analisar sistematicamente novas medidas de polícia nem para expor uma teoria da legislação criativa e complexa, em matéria de polícia.

Referências à atividade legislativa são encontradas em outro texto atribuído a Corrêa da Silva: a Explicação a alguns títulos da Ordenação, Livro $2 .{ }^{16}$ Pouco inovadora do ponto de vista teórico, a obra não fornece nenhuma análise detida da legislação no âmbito da "polícia". Longe disso, limita-se a expor didaticamente a tipologia de diplomas legais constante das Ordenações (Livro II, Títulos XXXIX e seguintes), permanecendo grosso modo fiel aos critérios preponderantemente formalistas de classificação que a orientavam. ${ }^{17}$

descabimento da crença em uma estagnação tão duradoura. Cf., entre outros, José Vicente Serrão, "O quadro humano". In: J. Mattoso (org.), História de Portugal, Lisboa, Estampa, [1993], v. 4, p. 50ss.

${ }^{14}$ Cf. Silva, Prelecções..., v. 2, f. 168-169. A tradicional distinção entre questões de justiça e questões de utilidade servia aqui para justificar a autolimitação da ciência jurídica em face do âmbito "político". Em outras obras e textos legais não faltam passagens indicativas do amplo emprego dado a esse critério de separação. Cf., e.g., Universidade de Coimbra, Estatutos da Universidade de Coimbra [1772], Coimbra, Universidade de Coimbra, 1972, v. 2, p. 317 (II, III, III, 4) e Telles, "Commentario..., p. 464.

${ }^{15}$ Cf. Ordenações filipinas [1603], reimpressão, Rio de Janeiro/Lisboa, Gulbenkian, 1985, 3 v., p. 31 ss. (L. I, T. IX); 39-41 (L. I, T. XII); 85ss. (L. I, T. XLVIII), 103ss. (L. I, T. LVIII) e 134ss. (L. I, T. LXV).

${ }^{16}$ Trata-se de uma cópia, finalizada em torno de 1809, de um texto sobre "Direito Pátrio". Aponta-se como autor, no próprio manuscrito, Luiz Joaquim de Figueiredo, um nome que não se encontra na lista dos lentes que teriam atuado nos cursos jurídicos de Coimbra (cf. Rodrigues, Memoria..., p. 89-131). Os temas aqui tratados e a coincidência de prenomes levaram Merêa, "Notas sobre alguns lentes..., p. 323, n. 10 e especialmente p. 326, n. 17, a apontar Luiz Joaquim Corrêa da Silva como o provável autor da obra.

${ }^{17}$ Cf., e.g., Silva, Prelecções..., v. 2, f. 230-231. 
Uma análise detida do que à época o próprio rei-legislador chamava de "Leis Politicas" e "Economicas" pressupunha, no entanto, o ordenar das "leis", "alvarás", "decretos" e "cartas de lei" não pela forma, mas sim pelo seu conteúdo e finalidade. Quem optasse por tratar desse tema tinha, pois, de perceber na lei o seu crescente caráter instrumental, dando-lhe mais atenção do que aos aspectos meramente formais. Tinha de pensar nas metas do legislador e nos campos da vida social abarcados pela atividade legislativa, que se expandia no final do Antigo Regime. Nesse sentido já pareciam caminhar, de certa maneira, as "Prelecções" de Ferreira Castello (m. 1824). ${ }^{18}$

A despeito de frequentes problemas de saúde, Castello conseguiu escrever numerosas páginas sobre as Ordenações filipinas quando passou a lecionar "Direito Pátrio" entre 1790 e 1795. As "Prelecções de Direito Pátrio" por ele deixadas analisavam também a "Lei da Boa Razão" de 1769, diploma que incluía no rol das fontes do direito - como vimos - as "Leis Politicas" e "Economicas" das "Nações Christãs, illuminadas, e polidas" da Europa. ${ }^{19}$ A contribuição das "Leys politicas" e "ecconomicas" para o "socego publico", para o "augmento dos Cabedaes dos Povos" e para a felicidade destes à "sombra dos Tronos" parecia a Castello digna de menção. Ele descrevia tais leis - inspirando-se na própria "Lei da Boa Razão" - como frutos do progresso da "Arithmetica politica" e da "ecconomica [sic] do Estado". Com isso, buscava legitimar não só a precedência das "Leys politicas" e "ecconomicas" em face especificamente do Direito Romano, mas também a sua aplicação preferencial como direito subsidiário. ${ }^{20}$

Forçoso é admitir, no entanto, que as "Prelecções" de Castello não veiculavam uma contribuição doutrinária original, no âmbito das "Leys politicas" e "ecco-

\footnotetext{
${ }^{18}$ Oriundo de uma família de juristas, José Cardozo Ferreira Castello iniciou em 1757 seus estudos em Coimbra, onde lecionou História do Direito Romano e do Direito Pátrio (1773-1781) e Direito Romano (1782-1789 e 1795-1800). Além de benefícios eclesiásticos de diversas dioceses, ocupou posições na Inquisição de Coimbra e na administração real. Após deixar a Universidade de Coimbra, tornou-se membro da Mesa da Consciência e Ordens (1801) e juiz das ordens militares (1818). Cf. Merêa, "Rol dos lentes", p. 327; Merêa, "Notas sobre alguns lentes..." p. 322-323; e Rodrigues, Memoria..., p. 114.

${ }^{19}$ Ver José Cardoso Ferreira Castello, Prelecções de direito pátrio, 1790/1795, Biblioteca da Universidade de Coimbra, Manuscrito, v. 4, f. 161ss., e o $\$ 9^{\circ}$ da lei de 18.8.1769, transcrita em Telles, "Commentario...", p. 454.

${ }^{20}$ Cf. Castello, Prelecções..., v. 4, p. 109-110, 162-163, 173, 199, entre outras.
} 
nomicas". Na verdade, o tema era, sobretudo, abordado nessa obra por meio da singela reprodução dos conteúdos da "Lei da Boa Razão".

Muito embora tal comportamento correspondesse perfeitamente ao ideal absolutista da submissão da doutrina ao legislador, o fato é que ia além do que se exigia, na prática, de um lente de "Direito Pátrio" em Coimbra. Os estatutos pombalinos da Universidade podiam até fixar a sequência de exposição dos temas da matéria e determinar um cuidadoso exame da "Lei da Boa Razão" - eles ainda deixavam ao professor, contudo, uma margem de liberdade nada desprezível, no que se referia à sistematização dos assuntos e normas dentro de cada uma das unidades temáticas previstas. ${ }^{21}$

As oportunidades decorrentes da existência dessa margem de liberdade para estruturar a matéria foram utilizadas mais intensamente por juristas mais criativos, como Paschoal de Mello Freire (m. 1798), e por Ricardo Raymundo Nogueira (m. 1827).

\section{4}

As "Prelecções de Direito Pátrio" de Ricardo Raymundo Nogueira não se limitavam, de modo algum, a expor a teoria da legislação por meio das palavras da "Lei da Boa Razão". Além disso, indicavam a tendência do autor para lidar sistematicamente com temas no âmbito da "polícia" e "economia" - se necessário deixando de seguir, ali, a estrutura das Ordenações. ${ }^{22}$

Beneficiário da intervenção de Pombal na Universidade de Coimbra, Nogueira iniciou sua carreira acadêmica como "Oppositor" no mesmo ano da reforma dos cursos jurídicos (1772). ${ }^{23}$ Vinculando-se ao Colégio das Ordens Militares,

${ }^{21}$ Cf. Coimbra, Estatutos..., p. 456-458 (II, VI, III, 3-5), 458 (II, VI, III, 9), 461-462 (II, VI, III, 21), 466 (II, VI, III, 37), 485 (II, VI, VI, 15) etc.

${ }^{22}$ Concluída por volta de 1795/1796, a obra somente foi publicada em 1858 pela Universidade de Coimbra, sob o título Prelecções de direito público interno de Portugal. Que a estrutura das Ordenações não correspondesse, ao ver de Nogueira, ao "methodo scientifico" é algo que pode ser verificado em seus Apontamentos para a reforma do curso de direito civil da universidade, 1787, Biblioteca Nacional de Portugal, Manuscrito, cod. 4676, f. 175.

${ }^{23} \mathrm{Na}$ reforma universitária, os antigos professores da Faculdade de Leis perderam suas cátedras, o que ali facilitou, evidentemente, a ascensão de juristas mais novos. Cf., e.g., Manuel Paulo Merêa, "Relação dos lentes das faculdades cânones e leis desde 1730 até a reforma pombalina", Boletim da Faculdade de Direito da Universidade de Coimbra, v. 34, 1958, p. 216-221, p. 221. Segundo algumas fontes, teria sido ainda maior a influência de Pombal sobre a carreira de Ricardo Raymundo. O 
assumiu posições na administração financeira da universidade, na Inquisição de Coimbra e em diversas dioceses. ${ }^{24}$ Lecionou na universidade, em períodos não coincidentes, Direito Romano e Direito Pátrio, obtendo a cátedra desta nova matéria em $1795 .{ }^{25}$ Posteriormente, Nogueira tornou-se reitor do Real Colégio dos Nobres (1802) e membro da Regência (1810) que respondeu pelo governo interno do reino, da fuga de Dom João para o Brasil até a Revolução do Porto. ${ }^{26}$

A exemplo de tantos letrados ibéricos influenciados pelo Iluminismo, Nogueira serviu lealmente à monarquia absolutista e defendeu-a em seus escritos, antes das invasões napoleônicas. Ele pertencia, então, àquela corrente política que buscava um compromisso entre a inovação e a preservação do existente, desejando viabilizar, por meio de um ativo absolutismo reformador, a atualização da sociedade estamental e a superação do atraso econômico e cultural português. ${ }^{27}$ Como reitor do Real Collegio de Nobres, Ricardo Raymundo envolveu-se pessoalmente nos esforços para modernizar a educação da nobreza. ${ }^{28}$ Como professor universitário e autor de projetos de reforma dos cursos jurídicos, porém, ele

secretário de Estado teria mesmo forçado a universidade a apressar o doutoramento deste, com o fim de produzir um "espectaculo literario" capaz de demonstrar o bom "estado das Artes, e das Sciencias em Portugal" e de assim impressionar favoravelmente um visitante da "mui culta Alemanha", o conde de Schaumburg-Lippe. Ver "Prefácio do editor". In: Ricardo Raymundo Nogueira, Prelecções de direito público interno de Portugal, Coimbra, Imprensa da Universidade, 1858, p. III, embora Joaquim Agostinho de Macedo, Elogio historico do illustrissimo e excellentissimo Ricardo Raymundo Nogueira, Lisboa, Impressão Regia, 1827, p. 9-10, advirta sobre o caráter anedótico do relato. Quanto aos "Oppositores" e sua posição nos cursos jurídicos, ver Coimbra, Estatutos..., p. 631 (II, XII, 7ss.).

${ }^{24}$ Cf., entre outros, Macedo, Elogio historico..., p. 11-12, 14-15, 17 e 22; "Prefácio do editor" a Nogueira, Prelecções..., p. III-IV; Innocencio Francisco da Silva, Diccionario bibliographico portuguez, Lisboa, Imprensa Nacional, 1862, v. 7, p. 162; Rodrigues, Memoria..., p. 213.

${ }^{25}$ Anteriormente, fora lente substituto de Direito Pátrio em diversos períodos (1782-1784, 1786 e 1789) e catedrático de Instituta (1790-1795). Cf. Merêa, "Notas sobre alguns lentes..." p. 323; e Rodrigues, Memoria..., p. 123.

${ }^{26}$ Cf., entre outros, Macedo, Elogio historico..., p. 26, 28, 30 e 40-41; “Prefácio do editor" a Nogueira, Prelecções..., p. IV; Silva, Diccionario bibliographico..., p. 162.

${ }^{27}$ Para uma comparação com a análoga corrente que existia na Espanha, cf., entre outros, Francisco Tomás y Valiente, Manual de historia del derecho español, Madri, Tecnos, 1996, p. 383-384, e Charles C. Noel, “Charles III of Spain”. In: H. M. Scott (org.), Enlightened Absolutism, 4. ed., Houndmills/ Londres, Macmillan, 1994, p. 119-143, p. 125, 128-130, 143, em especial.

${ }^{28}$ Cf. F. A. L. Vaz, "A difusão das idéias econômicas de Antonio Genovesi em Portugal", Cultura, v. 11, 1999, p. 563-567, p. 567. 
ainda considerava relevante, na década final do século XVIII, que se observassem as diferenças estamentais dentro do sistema de ensino. ${ }^{29}$

Lidar com o "Direito Pátrio" implicava entrar em contato com temas politicamente incômodos e potencialmente perigosos, como o significado das chamadas "leis fundamentais", as relações Coroa-súdito, as competências das assembleias estamentais ("Cortes") e a situação jurídica dos bens e privilégios da nobreza em face do poder real. Dentro desse contexto, um crítico do absolutismo dificilmente teria acesso à cátedra da disciplina na única universidade do país. Que Nogueira tenha se tornado catedrático é um veemente indício, portanto, de sua lealdade à monarquia absoluta. $\mathrm{O}$ mesmo se poderia dizer de sua nomeação como reitor do Real Collegio de Nobres - isto é, como principal encarregado da educação da nobreza do reino. ${ }^{30}$

À vista de escritos como "Apontamentos para a reforma do curso de direito civil" (1787) e "Prelecções de Direito Pátrio" (1795-1796), seria descabido ver Nogueira, na década de 1790, como um "liberal" ou "protoliberal". ${ }^{1}$ Não trazendo indícios suficientes nesse sentido, tais obras veiculam, pelo contrário, muitas ideias condutoras da concepção absolutista de Estado. As "Prelecções” proclamavam e legitimavam a supremacia da Coroa em face da nobreza, da Igreja, das Cortes, dos tribunais e dos governados em geral. ${ }^{32}$ Os "Apontamentos" negavam ao "Jurista" e ao "vassallo" mesmo o direito de questionar a justiça das leis régias:

${ }^{29}$ Cf., por exemplo, Nogueira, Apontamentos..., f. 166, 174 e 177, assim como Nogueira, Prelecções..., p. 135 e 137.

${ }^{30}$ Sobre as "leis fundamentais" do Antigo Regime, cf. A. C. L. Seelaender, "Notas sobre a constituição do direito público na idade moderna: a doutrina das leis fundamentais", Sequência, v. 53, 2006, p. 197-232, e, sobretudo, a precisa análise de Heinz Mohnhaupt, "Die Lehre von der Lex Fundamentalis und die Hausgesetzgebung europäischer Dynastien”. In: Heinz Mohnhaupt (Hrsg.), Historische Vergleichung im Bereich von Staat und Recht, Frankfurt am Main, V. Klostermann, 2000, p. 1-33. Para a nomeação e atividade no colégio, cf. Macedo, Elogio historico..., p. 26-28; Silva, Diccionario bibliographico..., v. 7, p. 162; Merêa, "Notas sobre alguns lentes..., p. 325; Rodrigues, Memoria..., p. 123; e Vaz, "A difusão das ideias..., p. 567.

${ }^{31}$ Para o primeiro texto, utilizamos o manuscrito que se encontra na Biblioteca Nacional de Portugal entre os papéis deixados pelo canonista Ribeiro dos Santos. Mesmo descrevendo Nogueira como um dos primeiros liberais, Míriam Halpern Pereira teve de reconhecer que as Prelecções de direito pátrio não veiculavam uma crítica do status quo inspirada no ideário liberal. Cf. Míriam Halpern Pereira (org.), Mouzinho da Silveira: obras, Lisboa, 1989, v. 1, p. 19-119, p. 99.

${ }^{32}$ Cf. Nogueira, Prelecções..., respectivamente: p. 11, 12, 14, 50, 91 e 98-99; p. 55 (confiram-se, também, p. 96, 136-137 e 154); p. 11-12, 14, 49-50, 90-91, 94-95, 97-99, 100-102 e 102-104; p. 91 e 117; e p. 4-5, 91 e 98 . 
reconhecer que estas refletiam "sempre [...] motivos de justiça e utilidade" seria pressuposto de toda correta interpretação das normas. ${ }^{33}$

Dentro desse quadro, seria evidente exagero ver no uso de termos como "cidadão" um indício de liberalismo ou protoliberalismo nessa fase do autor. Nas "Prelecções", o conceito de "cidadão" não apresentava função emancipatória nem conduzia à plena igualdade político-jurídica. Aparecendo aqui ao lado de termos como "vassallo" e "subdito", a palavra "cidadão" surgia mesmo em passagens sobre privilégios e diferenças estamentais. ${ }^{34}$

A posição política dessas obras também era condicionada - note-se - pelas circunstâncias de seu surgimento, por suas finalidades específicas e pelos destinatários visados pelo autor. Dependendo para sua execução do apoio da Coroa, a reforma curricular proposta nos "Apontamentos" naturalmente não podia ser exposta em um texto recheado de inoportunas críticas ao absolutismo. ${ }^{35}$

As "Prelecções" tampouco podiam ser moldadas como um texto de referência para aulas subversivas - estas seriam, aliás, praticamente inviáveis no ambiente coimbrão, mantido sob rígida vigilância. ${ }^{36} \mathrm{Na}$ verdade, tanto o conteúdo das "Prelecções" como sua orientação política foram consideravelmente condicionados pelas próprias finalidades principais da matéria "Direito Pátrio" - a efetiva transmissão das leis régias e a conversão das novas gerações de juristas em instrumentos do rei-legislador absolutista.

\footnotetext{
${ }^{33}$ Cf. Nogueira, Apontamentos..., f. 181 e 182; e f. 168.

${ }^{34}$ Cf., e.g., Nogueira, Prelecções..., p. 99, 106, 135, 181, 197.

${ }^{35} \mathrm{O}$ texto endereçava-se justamente àquele dirigente universitário que devia atuar como vínculo institucional entre a faculdade e a Coroa: o reitor Francisco Rafael de Castro. Cf. [Joaquim Fernando] Teophilo Braga, História da Universidade de Coimbra, Lisboa, Academia Real das Sciencias, 1898, v. 3, p. 723, como também Coimbra, Estatutos..., p. 640 (II, XIV, I, 10).

${ }^{36}$ A própria estrutura universitária servia ao propósito da vigilância. As duas faculdades de direito não estavam livres dos mecanismos intrauniversitários de repressão a opiniões incômodas à Coroa. O conteúdo dos livros, aulas e compêndios devia ser controlado pela congregação e por censores. Impunha-se denunciar as doutrinas que contrariassem os direitos e regalias da Coroa ou aquilo que ela própria visse como seu legítimo âmbito de poder. Cf. Coimbra, Estatutos..., p. 248 (I, VI, IV, 8-10), 638 (II, XVI, I, 2), 639 (II, XIV, I, 6), 640 (II, XIV, I, 11). A Carta Régia de 3.6.1782 também reforçou o controle sobre o corpo discente. As informações confidenciais sobre os estudantes, que cabia à universidade disponibilizar para o governo, também podiam ser usadas como arma política contra dissidentes. Ver Braga, História..., p. 666 ss.; Manuel Paulo Merêa, "Lance de olhos", Boletim da Faculdade de Direito da Universidade de Coimbra, v. 33, 1957, p. 187-214, p. 208-209; e Luís Reis Torgal \& Isabel N. Vargues, A Revolução de 1820 e a instrução pública, Porto, Paisagem, 1984, p. 193.
} 
A despeito disso e do comportamento de Nogueira durante a primeira invasão napoleônica (1807-1808), seria ir longe demais descrevê-lo como um inimigo oculto do absolutismo. Como reconheceu o próprio governo fugitivo, a colaboração com os franceses, nos estratos superiores da sociedade portuguesa, decorreu em parte da visão da queda dos Braganças como um fait accompli, que implicava uma mudança definitiva de regime. ${ }^{37} \mathrm{Na}$ Igreja, na Academia de Ciências, na maçonaria, na Universidade de Coimbra, na nobreza e na alta burocracia não faltaram indivíduos de destaque dispostos a se submeter rapidamente às forças de ocupação e a colaborar com elas. ${ }^{38}$ Nessa época, até mesmo os bispos portugueses chamavam Napoleão de "o Grande" e proclamavam publicamente a missão que esse "homem prodigioso" recebera de "Deus" de "amparar a religião e fazer a felicidade dos povos" ${ }^{39}$

Como outros integrantes da camada social representada pelos servidores mais ligados ao Iluminismo, Nogueira viu a ocupação francesa como uma oportunidade para impor reformas que, sob as condições até então existentes, tinham parecido quase irrealizáveis. ${ }^{40}$ Integrou um pequeno grupo que defendia,

${ }^{37}$ Veja-se a "Carta do príncipe regente para o bispo e junta do Porto", datada de 1808, citada em José Viriato Capela (org.), Política, administração, economia e finanças públicas portuguesas (17501820), Braga, ICS, 1993, p. 59 ss., em especial, p. 67. Ainda indefinidas as consequências da esperada mudança, o fortalecimento de um partido aristocrático francófilo e a manutenção da ordem estamental sob domínio napoleônico continuavam a representar uma das possíveis alternativas. Cf., e.g., Albert Silbert, Do Portugal do Antigo Regime ao Portugal oitocentista, 3. ed., Lisboa, Livros Horizonte, 1981, p. 65-67, 70 e 131-132; bem como Ana Cristina Bartolomeu de Araújo, "As invasões francesas e a afirmação das idéias liberais". In: José Mattoso (org.), História de Portugal, Lisboa, Estampa, 1998, v. 5, p. 21-40, p. 30-31.

${ }^{38}$ Cf. Silbert, Do Portugal..., p. 64; Araújo, "As invasões francesas..., p. 28 ss.; Raul Brandão, El-rei Junot, Lisboa, Imprensa Nacional/Casa da Moeda, 1982, p. 139 ss. e 154 ss., sobretudo; Jean de Pins, "Afrancesados portugais". In: Jean Tulard (org.), Dictionnaire Napoléon, Paris, Fayard, 1999, v. 1, p. 41-42; Jacome Ratton, Recordações de Jacome Ratton [Londres, 1813], 3. ed., Lisboa, Fenda, 1992, p. 281-282. Nesse contexto, o colaboracionismo envolvia até figuras influentes da Inquisição. Dom José Maria de Melo, que teria desejado anteriormente a excomunhão de todos os franceses, vinha agora descrevê-los, em 1807, como "irmãos" que deviam ser bem recebidos em Portugal. Cf. Brandão, El-rei Junot..., p. 141.

${ }^{39} \mathrm{Cf}$. as manifestações do patriarca de Lisboa e do bispo do Algarve reproduzidas em Brandão, Elrei Junot..., p. 141-142 (n. 3). Sobre o colaboracionismo da Igreja, cf. Silbert, Do Portugal..., p. 64, e Araújo, “As invasões francesas..., p. 29.

${ }^{40}$ Segundo uma "fonte napoleônica", poucas casas nobres portuguesas sobreviveriam à supressão do morgadio e dos conexos mecanismos de proteção contra credores. Cf. Silbert, Do Portugal..., p. 174. Para uma análise mais precisa do "endividamento aristocrático", ver, porém, Fernando Taveira 
à época, o uso da organização judicial e administrativa francesa como modelo para a reforma do Estado português. A plataforma política desse grupo também abrangia a igualdade jurídica entre os "cidadãos", a tolerância na esfera religiosa, a adoção do Code Napoléon em Portugal e a consequente liberação de todas as terras para o comércio. ${ }^{41}$

Em um período no qual as constituições se espalhavam com os exércitos franceses na Europa, tal grupo desejava que Bonaparte convertesse o país em uma monarquia constitucional. Uma constituição outorgada devia garantir a liberdade de imprensa, a independência da Justiça e a existência de um órgão representativo nacional, eleito indiretamente. ${ }^{42}$ Outorgando uma constituição e tornando rei de Portugal algum de seus familiares, Napoleão acabaria, na prática, com a sujeição do país ao general Junot, neutralizando politicamente, assim, também os círculos de aristocratas colaboracionistas que compunham o entourage do comandante francês. Tratava-se aqui, portanto, não só de defender reformas liberalizantes, pois, em jogo, estavam, igualmente, o poder político e posições no aparato estatal. ${ }^{43}$

Esse movimento constitucionalista lusitano, ainda que moderado nas metas e nos seus canais de expressão, não teve, porém, como se sabe, êxito. A resistência dos aliados de Junot, a falta de apoio do imperador francês e a queda do governo de ocupação (agosto de 1808) selaram o seu destino.

No caso de Nogueira, suas ações durante a ocupação não o impediram de chegar, já em 1810, ao que seria o ápice de sua carreira política. ${ }^{44}$ Embora classificado

da Fonseca, "Elites e classes médias". In: José Mattoso (org.), História de Portugal, Lisboa, Estampa, 1998, v. 5, p. 393-407, p. 395-396.

${ }^{41}$ Sobre tal grupo e seu programa político, ver Silbert, Do Portugal..., p. 131-132 e 174; Brandão, El-rei Junot..., p. 158; Halpern Pereira, "Estado e..., p. 32-33; Araújo, “As invasões francesas...", p. 31-32; J. Joaquim Gomes Canotilho, "As constituições". In: Mattoso (org.), História de Portugal..., v. 5, p. 125-139, p. 125-126; Zília Osório de Castro, “O pré-constitucionalismo em Portugal”, Cultura, v. 11, 1999, p. 389-399, p. 396 e 399.

${ }^{42}$ Cf. Dieter Grimm, Deutsche Verfassungsgeschichte 1776-1866, Frankfurt am Main, Suhrkamp, 1988, p. 56; Silbert, Do Portugal..., p. 66, 131-132, 174; Brandão, El-rei Junot..., p. 157-158; Halpern Pereira, "Estado e..., p. 32; Araújo, "As invasões francesas..., p. 31-32; Canotilho, "As constituições”..., p. 125-126; e Castro, “O pré-constitucionalismo ..., p. 397.

${ }^{43}$ Sobre o tema, ver, em especial, Silbert, Do Portugal..., p. 132; e Brandão, El-rei Junot..., p. 157.

${ }^{44}$ Menções à posição política dúbia que assumiu durante a primeira invasão francesa não cabiam em textos laudatórios como o Elogio historico do Illustrissimo e Excellentissimo Ricardo Raymundo Nogueira (1827). Nessa obra, editada pela Impressão Régia, a descrição de Nogueira como modelo 
por alguns de afrancesado, o jurista tornou-se, então, membro de uma regência aliada à Inglaterra e como tal seguiu auxiliando até 1820 a mesma monarquia absoluta que tanto servira anteriormente. ${ }^{45} \mathrm{~A}$ queda da regência e o triênio liberal (1820-1823) não puseram termo à carreira do jurisconsulto, que se tornou, derrotado o Vintismo, conselheiro de Estado, integrando a ala moderada do novo regime. ${ }^{46}$ Foi nesse cenário que elaborou para uma comissão especial do governo um projeto de constituição, cujo modelo foi a Charte constitutionelle francesa de $1814 .{ }^{47}$

Ainda que Nogueira invocasse reiteradamente o princípio tradicionalista da representação estamental, os "usos primordiaes da Nação" e a natureza supostamente "moderada" da "Monarquia Portugueza (...) desde sua origem", seu projeto de constituição era inovador para os padrões lusitanos. ${ }^{48}$ Disfarçada de restauração daquilo que teria sido a verdadeira constituição histórica do reino, darse-ia aqui a introdução, no país, de uma nova forma de governo. Sob o nome das velhas assembleias estamentais - "Cortes" - devia surgir, a rigor, um parlamento bicameral. ${ }^{49}$

Essa reconstrução nada isenta da história portuguesa se destinava, sem dúvida, a lastrear o projeto de constituição, tornando-o mais aceitável. Para atingir tal finalidade, Nogueira também se apropriou habilmente tanto do aparato

ideal do servidor da Coroa, sempre fiel à dinastia e ao absolutismo, servia manifestamente para finalidades propagandísticas. Não por acaso, seu autor era justamente uma das mais conhecidas vozes da Reação no debate político da época: José Agostinho de Macedo.

${ }^{45}$ Para uma descrição do grupo de Nogueira como "grupo francês" [sic], cf. Canotilho, "As constituições"..., p. 125. Sobre o conceito de afrancesado e sua identificação em Portugal com as ideias de traição, ateísmo, jacobinismo ou filiação maçônica, cf. Pins, "Afrancesados...".

${ }^{46}$ Cf. Manuel Paulo Merêa (org.), Projecto de constituição de 1823, Coimbra, Coimbra Editora, 1967, p. 7 ss., e Halpern Pereira, "Estado e..., p. 64.

${ }^{47}$ Sobre a influência da Charte constitutionelle, cf., entre outros, Merêa, Projecto..., p. 9 e 11, bem como Paulo Ferreira da Cunha, Para uma história constitucional do direito português, Coimbra, Almedina, 1995, p. 375 e 393, sobretudo.

${ }^{48}$ Cf. Ricardo Raymundo Nogueira, "Projecto da lei fundamental da monarquia portuguesa". In: Merêa, Projecto..., p. 19-31; Idem, "Rascunho incompleto de uma carta de lei fundamental". In: Merêa, Projecto..., p. 34; e Idem, "Bases duma lei fundamental". In: Merêa, Projecto..., p. 34. Comparar com a concepção veiculada pelo mesmo autor nas Prelecções..., p. 5, 97 e 100, de que Portugal fora desde sempre uma monarquia ilimitada, bem como a correspondente leitura pró-absolutismo da história nas p. 6-7, 11, 28, 66, 70, 94-95, 98 e 103-104.

${ }^{49}$ Cf. Nogueira, "Projecto...", p. 24. 
conceitual dos liberais quanto dos lugares-comuns do discurso político da reação absolutista.

Essa estratégia de legitimar soluções moderadas misturando os discursos dos extremos se evidenciava de forma clara em um "rascunho incompleto" da "Carta de lei fundamental". Aqui não era só a expressão "lei fundamental" que remetia à revalorização dos fundamentos da autoridade monárquica no Antigo Regime - tal papel também era desempenhado pelas invocações do "princípio sagrado da legitimidade", da "providencia" como base do governo e mesmo do "Braço do Omnipotente" como protetor da ordem política. Fechada a guarda à direita, Nogueira usava contra os vintistas o próprio vocabulário liberal. Já ganhava terreno, no "Rascunho", a crítica ao "Despotismo" e às ofensas aos "direitos dos Cidadãos" - mas tanto estas quanto aquela eram imputadas à "facção perfida" triunfante na Revolução do Porto.

No fundo, o projeto de constituição procurava um caminho intermediário entre o liberalismo de 1820 e as tendências mais radicais da reação. Sua meta era a harmonização do "princípio sagrado da legitimidade" com as "opiniões do seculo presente", já se proclamando ali a igualdade dos "Cidadãos [...] perante a Lei”. ${ }^{50}$ Tal igualdade não significava, porém, a total eliminação da ordem estamental.

Prevista expressamente, a liberdade de imprensa sofria limitações consideráveis, tendentes a esvaziá-la. O mesmo ocorria com a tolerância em matéria religiosa. Dotada de competência legislativa limitada, uma "2 $2^{\mathrm{a}}$ Camara" eleita "pelo Povo" deveria conviver com uma "1 ${ }^{a}$ Camara" de clérigos e nobres. Os membros desta e os ministros seriam nomeados apenas pelo monarca, cujo primado na estrutura estatal também seria alicerçado por um irrestrito direito de veto e pela condução, pelo trono, das Forças Armadas e da política externa. ${ }^{51}$

O projeto de Nogueira não pôde ser posto em prática. A instabilidade do país, a oposição de potências estrangeiras e a crescente radicalização das forças políticas tornaram-no inaplicável..$^{2}$ Seu êxito não interessava aos adeptos

\footnotetext{
${ }^{50}$ Esses aspectos se evidenciam, sobretudo, em Nogueira, “Rascunho...”, p. 32. Ver também Nogueira, "Projecto..., p. 29 e "Bases...", p. 34.

${ }^{51}$ Cf. Nogueira, "Projecto...", p. 19, 20, 24, 23, 26-29, 31 (impressa esta, por engano, como "13"); Nogueira, "Rascunho..., p. 32-33; e "Bases...", p. 34.

${ }^{52}$ Cf., entre outros, Merêa, Projecto..., p. 12 ss.; Cunha, Para uma história constitucional..., p. 376-378; Luís Reis Torgal, “Tradicionalismo absolutista e contra-revolução”. In: F. M. Costa/F. C.
} 
do absolutismo, cada vez menos dispostos a concessões. ${ }^{53}$ Produto da Reação, o projeto tampouco podia entusiasmar os herdeiros da Revolução de 1820. Autores de inspiração liberal chegaram mesmo a pôr em dúvida que Nogueira e os demais integrantes da comissão houvessem realmente produzido algum esboço de constituição. Como resultado, o projeto caiu em esquecimento já no século XIX. Redescoberto por volta de 1931 por um destacado juspublicista lusitano, o texto só veio a ser publicado em 1967 , por iniciativa do historiador do direito M. Paulo Merêa. ${ }^{54}$

Isso não basta para esclarecer o interesse relativamente reduzido que a obra de Nogueira tem despertado. Não por acaso, historiadores lusitanos registraram no passado, perplexos, a falta de trabalhos que examinassem detidamente todo o percurso do pensamento político de Nogueira e que considerassem a participação ativa e duradoura do jurista no governo regencial (tema, aliás, ainda longe de estar esgotado). Afinal, como advertiu Míriam Halpern Pereira, não se deu suficiente atenção ao fato de que o Nogueira da época de Junot é o mesmo que ressurgiu em $1823-1824 . .^{55}$

Ao menos comparadas à longa e coerente fidelidade de Mello Freire ao absolutismo, têm sido pouco estudadas a adaptabilidade de Nogueira e sua trajetória do oficialismo absolutista ao "liberalismo colaboracionista" de 1808 - e deste ao legitimismo e ao constitucionalismo moderado de 1823. Não tendo legado à posteridade tratados quase enciclopédicos como as "Institutiones juris civilis lusitani”, Nogueira não obteve, entre os juristas, a popularidade de um Mello Freire.

Classificados como "juspublicistas" no século XIX, seus escritos dos anos 1790 logo se tornaram obsoletos em decorrência de sua vinculação ao pensa-

Domingues/N. G. Monteiro (org.), Do Antigo Regime ao liberalismo, Lisboa, Vega, [s.d.], p. 93-103, p. 96, e Torgal \& Vargues, A Revolução de 1820..., p. 156.

${ }^{53}$ Ainda em 1845 deplorava um partidário do absolutismo miguelista a iniciativa do governo em 1823 de prometer a outorga de uma Carta Constitucional. Cf. Maria Teresa Mónica, "Um programa político miguelista”, Separata da Revista da Biblioteca Nacional, segunda série, v. 6/2, 1991, p. 19-51, p. 37.

${ }^{54}$ Cf. Merêa, Projecto..., p. 5-6, e Cunha, Para uma história constitucional..., p. 374.

${ }^{55}$ Halpern Pereira, “Estado e..., p. 33 (inclusive n. 24). Só recentemente Nogueira recebeu um estudo monográfico mais aprofundado, em trabalho orientado por Barbas Homem. Ver, também, José Luís Cardoso, O pensamento económico em Portugal nos finais do século XVIII, Lisboa, Estampa, 1989 , p. 209, além de alguns trabalhos isolados, que não tinham Nogueira como assunto principal, como Seelaender, Polizei... e Vaz, "A difusão das idéias...". 
mento político absolutista. Não surpreende, portanto, o fato de que, já por volta de 1870, Nogueira não figurasse no catálogo em que Candido Mendes elencava os mais relevantes "Jurisconsultos Portuguezes". Para a história do direito em Portugal, a importância dos escritos de Nogueira é, no entanto, inquestionável. ${ }^{56}$ Em particular, porque tais obras também se prestam a indicar em que medida o crescente interesse em Portugal pela "Polícia" e pela "Economia Civil" influenciaram, no reino, a ciência do direito.

\section{5}

O tratamento desses assuntos nas "Prelecções" não refletia apenas o dever do professor de "Direito Pátrio", de descrever todos os âmbitos do direito produzido pelo monarca. Como muitos integrantes da Academia das Ciências - à qual também pertencia -, Nogueira tinha um especial interesse por esse campo temático. ${ }^{57}$ Ele defendeu a introdução da "Economia Civil" no currículo da Faculdade de Leis e recomendou que a nova matéria fosse ensinada por um ano inteiro. ${ }^{58}$ Além da literatura jurídica, Nogueira lia também os "escriptores de economia", apreciando, sobretudo, o filósofo iluminista italiano Antonio Genovesi (m. 1769), cujas Lezioni di commercio o sia di economia civile (1765/1767) ele parcialmente traduziu. ${ }^{59}$

${ }^{56}$ Confira-se, por exemplo, a "Relação dos jurisconsultos portuguezes que florescerão em Portugal", publicada por Candido Mendes de Almeida, Auxiliar jurídico, Lisboa, Gulbenkian, 1985, p. 773. Para um levantamento recente das obras sobre Mello Freire, cf. Seelaender, Polizei..., p. 6 e 123 ss. Sobre a delimitação mais nítida do "Direito Público", sua mudança de função e a crescente relevância da dicotomia ius publicum/ius privatum na crise do "Ancien Régime”, cf. Michael Stolleis, Geschichte des öffentlichen Rechts in Deutschland, München, Beck, 1992, v. 2, p. 51-53, e A. C. L. Seelaender, "O contexto do texto: notas introdutórias à história do direito público na idade moderna", Sequência, v. 55, 2007, p. 253-286, p. 254 ss., e a bibliografia ali indicada. Sobre a contribuição pessoal à história do Direito dada por Nogueira como autor, bem como sobre o seu papel e influência na formação de numerosos juristas e servidores da Coroa, ver Macedo, Elogio historico..., p. 20 e 51.

${ }^{57}$ Para a participação na Academia das Ciências, cf. Macedo, Elogio historico..., p. 21, e Silva, Diccionario bibliographico..., p. 162. Segundo o primeiro, p. 14, Nogueira demonstrava desde por volta de 1772 interesse por "aquella tão util Sciencia, que se chama Economica, e Administrativa", grifo nosso.

${ }^{58}$ Cf. Nogueira, Apontamentos..., f. 168-180. Compare-se isso com Coimbra, Estatutos..., p. 277 (II, II, I, 1).

${ }^{59}$ Ver Nogueira, Prelecções..., p. 152. Nos anos 1820, o autor, ao que parece, valorizava muito os "conhecimentos das Sciencias políticas, e económicas". Cf. Nogueira, "Rascunho...", p. 32. Aliás, na Biblioteca Nacional de Portugal encontra-se um manuscrito intitulado "Lições de economia civil 
Segundo Nogueira, a Economia Civil era a ciência, que ensinava "os meios de fazer huma Nação populosa, rica, poderosa, polida, e bem costumada”. Ela mostrava, entre outras coisas, como "promover" - "para levar a Nação ao mais alto ponto de opulencia, força e civilização de que ella he capaz" - "a povoação, agricultura, industria e commercio". 60

Identificada com a "economia do Estado", a Economia não se ocupava com os "motivos de justiça" que inspiravam as decisões do legislador, mas, sim, com a "utilidade" que este buscava para o Estado. ${ }^{61}$ Em última análise, ela fornecia uma técnica para fortalecer Estados, na qual o crescimento populacional e o enrique-

e politica traduzidas das que escreveu em italiano o abbade Antonio Genovesi [...] por diligência do Doutor António Ribeiro dos Santos seu amigo e colega", códice 2168. Essa tradução, jamais publicada, mostra o grande interesse de Nogueira por questões relacionadas à educação, à economia e à evolução demográfica. Também revela sua simpatia pelo filósofo italiano, autor eclético influenciado por ideias fisiocráticas e mercantilistas. A difusão da Economia Civile genovesiana em Portugal foi favorecida por diversos fatores. A Itália funcionou como uma importante ponte na recepção do Iluminismo no país. Outros escritos de Genovesi já eram conhecidos em Portugal, tendo alguns deles servido mesmo como manuais de Metafísica e Lógica em escolas locais. Por fim, as preocupações de Genovesi e seu background cultural se assemelhavam muito aos dos portugueses que mais se incomodavam com o relativo atraso de seu país no contexto europeu. Sobre a influência de Genovesi em Portugal, cf., e.g., António A. Banha de Andrade, Contributos para a história da mentalidade pedagógica portuguesa, Lisboa, Imprensa Nacional/Casa da Moeda, 1982, p. 624 e 635-636, sobretudo; José Esteves Pereira, O pensamento político em Portugal no século XVIII, Lisboa, Imprensa Nacional/Casa da Moeda, 1983, p. 91 ss., 179, 207-208, 336 (n. 1); José Joaquim Lopes Praça, História da filosofia em Portugal, 3. ed., Lisboa, Guimarães Editora, 1988, p. 276-278, 294-295 (n. 47); Cardoso, O pensamento económico..., p. 305; Francisco José Calazans Falcon, A época pombalina, 2. ed., São Paulo, Ática 1993, p. 78 (n. 218); Fernando A. Novais, Portugal e Brasil na crise do antigo sistema colonial, 6. ed., São Paulo, Hucitec, 1995, p. 229-230; e sobretudo Vaz, "A difusão das idéias..., p. 553-554 e 561 ss. Quanto à maneira de Nogueira lidar com as ideias de Genovesi, cf., além da tradução supracitada, Vaz, "A difusão das idéias...", p. 563 ss.

${ }^{60}$ Nogueira, Apontamentos..., f. 168v, e 174v. O mesmo ideal de maximização das bases do poderio estatal pode ser encontrado tanto em Genovesi quanto nos tratados de polícia disponíveis na Biblioteca da Universidade de Coimbra. Ver Antonio Genovesi, "Lições de economia civil e política traduzidas...", [s.d.], trad. de Ricardo Raymundo Nogueira, Biblioteca Nacional de Portugal, manuscrito, códice 2168, f. 1, e Johann Heinrich Gottlob von Justi, "Préface”. In: Élémens généraux de police [Grundsätze der Policeywissenschaft, 1756], Paris, Benoît Rozet, 1769, p. 3: "augmenter ses forces \& sa puissance autant qu'il en est capable".

${ }^{61}$ Nogueira, Prelecções..., p. 121. A Economia Civil ensinava, ao ver do autor, "noçoens geraes do que he util, ou prejudicial ao bem do Estado". Já o que era justo ou injusto competia ao Direito Natural definir. Ver Nogueira, Apontamentos..., f. 168v e 173v, sobretudo. 
cimento dos governados eram vistos e tratados sobretudo como meios, não como finalidades em si. $^{62}$

A Economia não deveria, porém, apenas orientar, como um saber técnico, a gestão estatal nos quadros do absolutismo. Também tinha por função legitimar as leis da monarquia absoluta. Cabia à "Economia Civil", como matéria universitária, revelar aos futuros legistas a "utilidade" das leis reais e esclarecer quais eram os prováveis motivos de "interesse publico" a elas subjacentes. Nesse contexto, ela devia ajudar na busca da real intenção do legislador, sem servir, no entanto, como instrumento de crítica a este último.

De acordo com os "Apontamentos", “o Jurista" não devia nunca declarar a lei do soberano imprópria "para o fim a que se encaminha" - nem mesmo quando as razões de sua existência lhe parecessem insuficientes ou lhe continuassem inapreensíveis. Como ciência auxiliar da interpretação jurídica, a Economia devia capacitar os juristas para identificar as prováveis razões políticas das leis, fazendo-os observarem melhor, na aplicação do Direito, a vontade do legislador. ${ }^{63} \mathrm{O}$ objetivo de tal capacitação consistia, pois, no aumento da efetividade do poder da Coroa quanto ao exercício da atividade legislativa.

Na segunda metade do século XVIII, ao acentuar-se a preocupação da Coroa portuguesa com as bases do poderio estatal (como o número de súditos e a situação dos diferentes ramos da economia), ocorreu uma notável intensificação da atividade legislativa. ${ }^{64} \mathrm{~A}$ lógica da nova legislação, contudo, precisava ser apreendida pelas novas gerações de juristas. Nesse contexto, a matéria "Economia" deveria assumir a missão de tornar essa lógica compreensível, impedindo o aplicar "errôneo" da nova legislação, que poderia sabotar os esforços governamentais.

Essa concepção da Economia Civil como um instrumento auxiliar da interpretação das leis correspondia, em última análise, à tendência, então verificada, para um influenciar recíproco, por parte dos discursos jurídico e econômico. A

${ }^{62}$ Cf. Nogueira, Apontamentos..., f. 174, e Prelecções..., p. 136. Essa ideia de instrumentalidade do econômico correspondia, aliás, a uma das principais tendências do discurso mercantilista. Cf. Eli F. Heckscher, La época mercantilista, México, Fondo de Cultura Económica, 1983, 1983, p. 9, 463 ss., 466, em especial.

${ }^{63}$ Ver Nogueira, Apontamentos..., f. 171. Cf. também p. 168-169 e 181.

${ }^{64}$ Para uma análise do fenômeno, cf. Seelaender, Polizei..., p. 46 ss. Já comprovando sua ocorrência em comparação com o reinado de Dom João V, António Manuel Hespanha, "Nota do tradutor". In: John Gilissen, Introdução histórica ao direito, Lisboa, Gulbenkian, 1988, p. 321-323, que, no entanto, excluía de sua contagem um dos veículos preferenciais da nova legislação: os alvarás. 
mesma concepção justificava a proposta de Nogueira de introduzir a matéria nos cursos jurídicos, e não na faculdade que devia abarcá-la como objeto "filosófico". Não era o lugar da Economia no sistema vigente das ciências, mas sim a sua relevância como referência para todos os ramos do Direito que deveria determinar, aqui, a qual faculdade o curso viria a se vincular. ${ }^{65}$

Como ciência e esfera específica da ação estatal, a Economia Civil se relacionava a todos os ramos da atividade econômica. Segundo as "Prelecções", ela se ocupava de assuntos como "educação", "industria", "commercio", "pureza dos costumes", tamanho da população, cultivo das "artes e profissões", "segurança pública", abastecimento de víveres e "bom estado dos logares públicos". Os três últimos temas pertenciam, mais precisamente, à "policia", que Nogueira definia como "ramo da economia civil".

Ainda segundo as "Prelecções", a polícia se ocupava propriamente da "segurança dos cidadãos", da "bondade, abundancia, e justo preço" das mercadorias e do "bom estado, e uso commodo das ruas, estradas e logares públicos". Ela competia aos "magistrados de policia" - também chamados de "magistrados politicos". Entre estes encontraríamos tanto os tradicionais representantes da administração citadina - e.g., os almotacéis, os vereadores e os juízes ordinários - quanto servidores da Coroa stricto sensu, como o intendente geral da polícia e os intendentes "de obras públicas" (e.g., os que se ocupavam das estradas ou dos rios Douro e Mondego). Compreender-se-iam aqui também diversos juízes reais (corregedores, juízes de fora, desembargadores da Casa da Suplicação, chanceler da Relação do Porto etc.), que, no normal exercício de seus ofícios ou com base em funções suplementares ("comissão"), tivessem de tratar de matérias tidas por policiais (serviços de vigilância, identificação de "clerigos travessos e revoltos", controle de armas, obras públicas, estalagens, inspeção de pontes, estradas e fontes etc.). ${ }^{66}$

${ }^{65}$ Traçando um paralelo entre o Direito Natural e a Economia Civil, o autor situa ambos na Filosofia,
mas defende seu ensino nas faculdades jurídicas. Ver Nogueira, Apontamentos..., f. 173 (em especial,
a n. "a"). Do ponto de vista formal, a despeito do anterior ensino das "Artes" em Coimbra, somente
em 1772 se fundou ali uma faculdade de Filosofia. As ciências naturais constituíam o núcleo do cur-
rículo, que não incluía matérias como "Política", "Economia" ou "Ciência da Polícia". Cf. Coimbra,
Estatutos..., p. 228 (III, III, II, II, 1-4) e 230 (III, III, II, II, 7) e Rodrigues, Memoria..., p. 269.
${ }^{66}$ Ver Nogueira, Prelecções..., p. 135-136, 143, 152-157. Segundo o autor, tal definição correspondia
ao conceito de polícia "em significação estricta", que em regra seria aceito pelos "escriptores de eco-
nomia". Um conceito alternativo mais amplo, contudo, não chega a ser mencionado nas Prelecções... 
Nogueira tentou classificar os "magistrados" em específicos "ramos de jurisdicção". Reconhecendo a existência de diferentes esferas de atividade estatal, ele não podia deixar de registrar que, em Portugal, o processo de separação dessas mesmas esferas ainda não havia se completado. Entre os "magistrados do nosso reino" - diziam as "Prelecções" - "nenhum há, cuja jurisdicção se limite a um só gênero de negócios”. Por não serem sempre observadas as diferenças que existiam entre os vários "ramos de jurisdicção", ainda competiam aos magistrados numerosas tarefas inapropriadas ("muitas cousas desvairadas"). ${ }^{67}$ Como percebia Nogueira, no final do século XVIII os juízes ainda participavam da polícia e do "governo econômico" local. O chanceler da Relação do Porto detinha a "comissão" de "inspector geral das obras públicas"; juízes lisboetas buscavam "pessoas de ruim viver" nas estalagens. Esse acúmulo de funções não era, de qualquer modo, o único obstáculo para o prosseguimento do processo de separação das esferas de atividade estatal. Tendo diversas finalidades ao mesmo tempo, algumas tarefas - como o combate à vadiagem - podiam ser simultaneamente classificadas em vários "ramos de jurisdicção". 68

Nas "Prelecções", a análise das diferentes esferas da atividade estatal não desembocava, contudo, em uma apologia explícita da separação de poderes. Nogueira lera De lesprit des lois e falava ocasionalmente de um "poder judiciario", mas sua imitação de Montesquieu não ia tão longe que o levasse a contestar os próprios fundamentos da monarquia absoluta. ${ }^{69}$ Nada prenunciava, aqui, o posterior empenho de Nogueira pela independência da Justiça. Segundo as "Prelecções", a existência e a autoridade dos órgãos judiciais não se assentavam nas prestigiosas "leis fundamentaes", decorrendo, na verdade, apenas de "leis [...] puramente civis", passíveis a todo momento de alteração pelo rei. ${ }^{70}$

(cf. p. 152). Ver também Nogueira, Apontamentos..., f. 174-174v. Também nesse ponto, não se deve excluir a possível influência de Genovesi.

${ }^{67}$ Nogueira, Prelecções..., p. 121-122.

${ }^{68}$ Ao lado da finalidade policial da segurança - o combate à "vida livre e licenciosa" geradora de "homens viciosos" tendentes ao crime -, havia aqui outra finalidade, esta meramente econômica: "fomentar a indústria" das classes baixas procedendo "contra os vadios e mendigos". Cf. Nogueira, Prelecções..., p. 153. Ver, ainda, p. 152 e 155 (em exame conjunto), como também p. 152-157, além de Genovesi, "Lições de economia civil e política traduzidas..., f. 304.

${ }^{69}$ Cf., respectivamente, Nogueira, Prelecções..., p. 10 (n. 1) e p. 134.

${ }^{70}$ Compare-se, por exemplo, a proibição da demissão arbitrária de juízes no projeto de Constituição de 1823 em Nogueira, “Projecto..., p. 29, com Nogueira, Prelecções..., p. 91. 
Não faltavam nas obras de Nogueira pontos de apoio para sustentar a superioridade do legislador em face da Justiça. Sua concepção do "direito de legislar" real como cerne da soberania, seu conceito de lei radicalmente voluntarista e sua defesa da vinculação do juiz às leis esvaziavam o "poder judiciario". Em caso de necessidade, podia o rei-legislador neutralizar este último por meio de dispensas, isenções e atos de graça. ${ }^{71}$ Importante notar, aliás, que Nogueira via a concessão de dispensas e privilégios como expressão do próprio poder de legislar: "só o legislador supremo" podia "conceder privilegios, porque só elle" tinha "auctoridade de dispensar nas leis" gerais por ele mesmo criadas. ${ }^{72}$

Por trás da concessão dos privilégios e da aplicação de sanções punitivas e prêmios, Nogueira via um legislador desejoso de dirigir "as acções dos cidadãos" no sentido da "conservação e melhoramento do Estado". As "Leis Civis" editadas pelo rei visavam à prosperidade da "Nação", ao fortalecimento do "Corpo Politico" e à cura de suas "enfermidades". Tais leis refletiam, assim, não apenas a vontade do governante absoluto, mas também nobres "motivos [...] de utilidade". Nesse contexto, a ideia de uma resistência judicial às leis reais parecia, em última análise, destituída de sentido. O monarca era o "primeiro motor" da "grande machina" do Estado; dentro dessa "machina" devia a Justiça, a rigor, exercer uma função meramente instrumental. ${ }^{73}$

\footnotetext{
${ }^{71}$ Segundo Nogueira, "a lei é a norma prescripta pelo soberano a seus subditos, para por ella regularem suas acções". Ela "recebe [...] toda a sua força da vontade do summo imperante" (Nogueira, Prelecções..., p. 107). Ver, ainda, ibidem, p. 106, e Nogueira, Apontamentos..., f. 166. Já quanto à Graça, as posições de Nogueira não eram originais em Portugal do Antigo Regime. Ali já existiam, inclusive, antigos órgãos específicos ligados à Coroa, competentes para o exame de matérias inseridas no âmbito da "Graça". Cf., por exemplo, Nogueira, Prelecções..., p. 129 e 159 ss. Segundo Nogueira, "a lei é a norma prescripta pelo soberano a seus subditos, para por ella regularem suas acções". Ela "recebe [...] toda a sua força da vontade do summo imperante" (Nogueira, Prelecções..., p. 107). Ver, ainda, ibidem, p. 106, e Nogueira, Apontamentos..., f. 166.

${ }^{72}$ Cf. Nogueira, Prelecções..., p. 99. Sobre o tema, ver também Michael Stolleis, "Condere leges et interpretari”. In: Staat und Staatsräson in der frühen Neuzeit, Frankfurt am Main, Suhrkamp, p. 167-196.

${ }^{73}$ Ver Nogueira, Prelecções..., p. 106; Nogueira, Apontamentos..., f. 168; e, no mesmo sentido, Nogueira, Prelecções..., p. 107, 140, 83 e 81; assim como Nogueira, Apontamentos..., f. 169. No século XVIII, essa utilização concomitante das metáforas do corpo e da máquina não parecia de modo algum contraditória. Nos textos políticos da época, o corpo não era usualmente entendido "no sentido do moderno conceito de organismo", mas sim com base na "analogia do mecanismo". Cf. Barbara Stollberg-Rillinger, Der Staat als Maschine, Berlim, Duncker \& Humblot, 1986, p. 109 e 111, sobretudo.
} 
Todos os agentes estatais - inclusive os "magistrados economicos" e os "magistrados de policia" - seriam instrumentos do legislador e executores de sua vontade. Órgãos como a "Real Junta do Commercio, Agricultura, Fábricas e Navegação" deviam "vigiar na execução das leis já estabelecidas", eventualmente propondo ao governo novas medidas mais eficazes. Assegurar a "observância das leis" era, por sinal, um dever dos "deputados" das sociedades mercantis privilegiadas, da censura real, do "fiscal dos diamantes" e de muitos outros agentes e órgãos coletivos. Note-se, aliás, que as "Prelecções" tendiam mesmo a descrever a ação "policial" ou "econômica" como uma simples realização da vontade do legislador. ${ }^{74}$

Nogueira não ignorou o "governo economico" das cidades nem a conexa atividade legislativa no âmbito local. As "Prelecções" tratavam, por exemplo, da regulação municipal das relações de trabalho, inclusive fixando valores máximos para este último. Abordavam o abastecimento de víveres e assuntos próximos ou correlatos - tais como o controle e a fixação de preços, o combate aos monopólios e a fiscalização da qualidade dos alimentos.

Segundo Nogueira, "sobre todos estes pontos devem as camaras fazer posturas". No entendimento do autor, as posturas eram "accordãos, estatutos e regulamentos" do concelho como "corporação". Elas se referiam ao "governo económico do concelho, preços de mantimentos e outras cousas" da vida local, cabendo a servidores da administração concelhia - como os almotacés - zelar por sua aplicação. De "tanta auctoridade" gozariam as posturas, que somente o próprio rei poderia revogá-las, quando feitas regularmente. Era, no entanto, possível que os corregedores examinassem a origem das posturas, declarando-as "nullas" se verificassem aqui a inobservância dos procedimentos legalmente exigidos. É interessante registrar que Nogueira sequer cogita de tal hipótese, quando analisa paralelamente as leis reais sobre temas policiais e econômicos. ${ }^{75}$

\footnotetext{
${ }^{74}$ Nogueira, Prelecções..., p. 152. Para indícios do papel de magistrado como instrumento do monarca, cf., e.g., Nogueira, Prelecções..., p. 174. Citação na p. 143. Nas p. 148-149, o autor salienta existir em "cada uma d'estas sociedades" um "fiscal" com o específico dever de promover essa "observancia". O comentário sobre a Real Mesa Censória e o análogo órgão que a sucedeu encontra-se nas p. 137-138. Ver, ainda, p. 145.

${ }^{75}$ Nogueira, Prelecções..., p. 155. Ver, ainda, p. 146 e 155-158. Citações extraídas da p. 156, em que também encontramos uma singela exposição do conteúdo das Ordenações filipinas [1603]..., v. 1, p. 104-105 (I, LVIII, 17). Também descrevendo as posturas como "Acórdãos", cf. Correa da Silva, Prelecções..., v. 2, f. 71. Talvez possamos ver, nesses termos sobrepostos, uma marca da transição
} 
Sobre o problema da eficácia das leis - aqui incluída a legislação econômica e de polícia - não silenciam as obras de Nogueira. Ele salientou a importância de rápidos processos decisórios no âmbito da polícia e lamentou que velhas leis nessa área caíssem em esquecimento. Via na dificuldade para aplicar certas leis uma "experiencia" digna de atenção. A experiência também podia ser útil na hora de regular matérias então vistas como tipicamente econômicas. ${ }^{76}$

De acordo com a legislação lusitana, "magistrados politicos e econômicos", como o "Intendente Geral da Policia", podiam deixar de lado muitas formalidades do procedimento judicial ordinário, quando se tratasse de punir mendigos e vadios ou de forçá-los a trabalhar. Esse procedimento especial menos formalizado não se fundava apenas no direito do "legislador" de obrigar os "cidadãos" a contribuírem "com as suas forças e indústria para a opulência do Estado". Nogueira também acreditava que no âmbito da "economia" e da "polícia" deviam valer regras específicas no campo processual. Por sua própria natureza, casos referentes a objetos da polícia demandavam rápidas soluções por meio de rápidos processos. ${ }^{77}$ Como vemos, aqui importava mais a efetiva aplicação das leis policiais e econômicas do que o aprofundamento da discussão sobre a justiça de sua aplicação em cada caso concreto.

Nem ponderações de justiça nem concessões ao ideal jusracionalista da sistematicidade distanciavam Nogueira de sua concepção básica de que a vontade real era a verdadeira fonte da validade das leis. Por isso mesmo, a fiel descrição destas últimas (como ordens do soberano) lhe parecia mais importante do que a "exactidão" de sua organização sistemática segundo o "methodo Mathematico".

de Satzung para Gebot, na tipologia de Wilhelm Ebel, Geschichte der Gesetzgebung in Deutschland, Göttingen, O. Schwartz, 1988. Para a atitude dos corregedores quanto às posturas, cf., por exemplo, Nogueira, Prelecções..., p. 135 ss. e 152-158. Uma relativização dos aspectos formais de certos tipos de lei pode, aliás, ser encontrada em Nogueira, Prelecções..., p. 109-110 e 112-113.

${ }^{76}$ Ver, e.g., Nogueira, Prelecções..., p. 191; e Nogueira, Apontamentos..., f. 185, que versa sobre a "cola" no âmbito da educação universitária.

${ }^{77}$ Cf., e.g., o decreto de 4.11.1755 e o Alvará de 25.6.1760. In: Appendix das leys extravagantes, decretos e avisos, Lisboa, Mosteiro de São Vicente de Fora, 1760, p. 387 e 309 (n. 19), respectivamente; além do alvará de 15.1.1780. In: António Delgado da Silva, Collecção da legislação portugueza, Lisboa, Typ. Maigrense, 1828, p. 255-256. Ver, ainda, Nogueira, Prelecções..., p. 140. Sobre o "processo de polícia" no Antigo Regime, com o registro de posições discordantes sobre a funcionalidade desse conceito, ver A. C. L. Seelaender, "A polícia e as funções do Estado", Revista da Faculdade de Direito UFPR, v. 49, 2009, p. 73-88, p. 79, e Simon, Gute Policey..., p. 355ss. 
Nas "sciencias de authoridade" como a "Jurisprudencia Civil", não era necessário, no ver de Nogueira, "demonstrar tudo mathematicamente". ${ }^{78}$

Nogueira adotava um conceito voluntarista de lei que não favorecia o uso crítico de princípios de direito natural na análise do "direito pátrio". Em sua opinião, o direito natural devia mostrar que as leis eram justas - mas questionar essa justiça era algo que não cabia ao jurista. Tratava-se, pois, de um direito natural preponderantemente legitimador, que não visava, em última análise, a limitar realmente o poder do legislador. ${ }^{79}$

Identificando incondicionalmente a lei com a vontade mutável do monarca absoluto, Nogueira podia também justificar, implicitamente, distanciamentos do legislador em relação aos pontos de vista tradicionais sobre os "bons costumes", mesmo quando estes se vinculassem a ditames religiosos. Nas "Prelecções" já era perfeitamente possível descrever como uma simples curiosidade, sem observações moralizantes, a substituição da proibição legal dos jogos de cartas por privilégios régios de comercialização de baralhos ${ }^{80} \mathrm{O}$ autor, aliás, não tendia a contestar nem a mutabilidade das leis nem a possibilidade de criação de direito novo. ${ }^{81}$

Dessa possibilidade dependia em parte a crescente intervenção do legislador no âmbito da Economia Civil - inclusive nas atividades econômicas na acepção hoje predominante desse termo. Longe de questionarem tal intervenção, as "Prelecções" lançavam mesmo críticas à irracionalidade do mercado. ${ }^{82}$ Em tal obra figuravam, lado a lado, manifestações favoráveis ao princípio do "justo preço" e à "liberdade dos movimentos" na esfera econômica; nela não se atacavam nem as corporações de ofício nem a prática de fixar normativamente o preço dos produ-

\footnotetext{
${ }^{78}$ Cf. Nogueira, Apontamentos..., f. 175. Tal entendimento correspondia, também, à crença do autor de que os "textos" do direito vigente continham "decisoens e não principios" (ibidem).

${ }^{79}$ Cf. Nogueira, Apontamentos..., f. 171 e 181-182. Neutralizava-se nesse contexto o potencial crítico da ideia de que o Direito Natural esclarecia o que o legislador "podia fazer". Ver Nogueira, Apontamentos..., f. 169.

${ }^{80}$ Cf. Nogueira, Prelecções..., p. 179 (n. 2).

${ }^{81}$ A crença de Nogueira na mutabilidade do Direito refletia também a sua tendência para analisar as instituições sociais a partir de uma perspectiva evolucionista. A conexão das leis com o "estado de civilisação" e com o correlato "systema de governo" implicava, naturalmente, a mutabilidade delas próprias. Cf. Nogueira, Prelecções..., p. 7-9. Pensando nessa mesma conexão, o autor podia até, em princípio, ter concebido limitações fáticas ao poder do legislador. Nogueira, contudo, não desenvolveu essa linha de argumentação no que tange ao rei-legislador de sua época - ao menos nas fontes aqui consultadas.
}

${ }^{82}$ Cf. Nogueira, Prelecções..., p. 150. 
tos e da mão de obra ${ }^{83} \mathrm{~A}$ intervenção estatal era apresentada aqui como um fator de racionalização da economia: "enganados pela cobiça indiscreta de levarem muito, com pouca despesa", os "commerciantes" acabariam arriscando irresponsavelmente o seu próprio patrimônio, se, por exemplo, o "governo" não vigiasse com rigor o comércio marítimo. ${ }^{84}$

Essa tendência das "Prelecções" de aceitar implicitamente ou mesmo de apoiar a intervenção estatal correspondia, à época, a orientação dominante no discurso "econômico" português. Ela também era, por sinal, totalmente compatível com a defesa de um papel ativo da Coroa, na criação do direito ${ }^{85}$

6

Os escritos de Nogueira antes das invasões napoleônicas nos mostram, em suma, o emprego de conceitos-chave do discurso absolutista, na hora de legitimar a expansão da atividade legislativa real e de reclamar a submissão do meio jurídico às leis do absolutismo reformador. As ideias de "polícia", "economia" e "governo econômico" tendiam a marcar, nessa época, espaços abertos ao rei-legislador e a seus agentes; a indicar esferas em que o monarca, implicitamente equiparado ao pai de família no gerir da "grande casa" do reino, dispunha de um amplíssimo poder de regular, ordenar e impor condutas. Esferas em que perdiam força vários limites que a tradição jurídica havia, desde a Idade Média, imposto na prática aos reis ("iura quaesita", ideal do rei-juiz semi-inerte, privilégios estamentais).

$\mathrm{Na}$ fase posterior a 1807 , as características de pensador de transição se acentuaram em Nogueira, tendo ocorrido, como vimos, uma parcial assimilação do vocabulário liberal. A este deu o autor, contudo, um uso estratégico conveniente para a sua corrente política. Por vezes, suavizou os significados originais, reduzindo suas implicações potencialmente subversivas. Outras vezes, alargou ou deturpou habilmente tais significados, para estender às ações dos liberais termos de carga negativa, por estes usados no ataque ao absolutismo.

\footnotetext{
${ }^{83}$ Cf. Nogueira, Prelecções..., p. 135, 152, 174-175 e 145-146.

${ }^{84}$ Cf. Nogueira, Prelecções..., p. 150-151.

${ }^{85}$ Para um exame da correspondência entre o ideal do legislador ativo e a ampla concepção que Nogueira tinha dos fins do Estado, ver, e.g., Nogueira, Prelecções..., p. 106-107, 140 e 141-142.
} 
Em autores de transição como Nogueira, Cairu e José Bonifácio, uma análise mais detida da linguagem pode indicar a necessidade de uma relativização de antigas classificações que acentuam demasiadamente contrastes e rupturas entre o Antigo Regime e o liberalismo. Aqui, seguir a trilha dos conceitos - verificando, e.g., a adaptação de velhas palavras a novas circunstâncias políticas - pode mostrar-se uma boa estratégia de pesquisa. 